\title{
A method for isolating smooth muscle cells from pig urinary bladder with low concentrations of collagenase and papain: the relation between calcium concentration and isolated cell length
}

\author{
R. Schot, E. van Asselt, R. van Mastrigt \\ Department of Urology, Room \#EE 1630, Erasmus University Rotterdam, PO Box 1738, 3000 DR Rotterdam, The Netherlands
}

Received: 26 May 1992 / Accepted: 12 August 1992

\begin{abstract}
Summary. The present study describes a method for isolating single smooth muscle cells from pig urinary bladder using a continuous resuspension device. Low concentrations of collagenase and papain were sufficient to obtain a high yield of viable smooth muscle cells, which remained viable for about $3-4 \mathrm{~h}$ as tested with fluorescein diacetate. Addition of fetal calf serum increased the lifespan of the isolated cells and the percentage of contractile smooth muscle cells, but caused spontaneous shortening of the cells. The length and volume of the isolated smooth muscle cells depended on the calcium concentration used in the isolation buffer solution. The isolated muscle cells were apparently relaxed if a calcium concentration less than $1.0 \mathrm{mmol} / 1$ was used in the isolation medium. In higher calcium concentrations the isolated cells were significantly shorter, probably as a result of a contraction caused by mechanical stimulation of the cells during the isolation procedure.
\end{abstract}

Key words: Bladder - Calcium - Cell isolation - Contraction - Smooth muscle

The contractility of the urinary bladder muscle has been investigated for many years using the whole bladder, bladder strips $[11,15,16]$ and isolated muscle bundles [12]. Measurements on isolated single smooth muscle cells are necessary for a complete understanding of smooth muscle contractility. Isolation procedures for smooth muscle cells from different organs were first described in 1971 [2], but the isolation of smooth muscle cells from bladder tissue proved to be extremely difficult, probably because of both the high concentration of collagen between and around the muscle cells [9] and the many close contacts between the cells [10]. The pig bladder has proved to be a good model for the human urinary bladder both anatomically and physiologically [4].

Correspondence to: R. Schot, MD; FAX: $31(10) 4366428$ (not available on tuesdays)
A procedure for isolating smooth muscle cells from pig urinary bladder using collagenase and papain has already been developed [17]. Isolation techniques using papain have also been described $[6,13,14]$. With the previous procedure, though, a very poor yield of viable smooth muscle cells was obtained. Although the lengths of the isolated smooth muscle cells corresponded with the lengths described by van Dijk and Laird (bovine coronary artery) [5], Glerum (pig urinary bladder) [9] and Maruyama (guinea pig taenia coli) [13,14], the single cells were much shorter than the smooth muscle cells observed in muscle strips from swine carotid artery [6]. To obtain a better yield and cells of more physiological lengths, the previous isolation method was modified by applying a special device for repeatedly resuspending up to four smooth muscle suspensions simultaneously. In this way the isolation time was reduced to $30 \mathrm{~min}$ while the enzyme concentrations were reduced to one third of those used previously.

In this study the modified isolation method is described and verified by studying the dependency of the length of the isolated cells on the calcium concentration of the buffer used. The length dependence of isolated cells on the degree of strain of the bladder was also investigated.

\section{Materials and methods}

Thirty successive isolation procedures were performed according to the following method. At the local slaughterhouse two pig bladders were obtained a maximum of $15 \mathrm{~min}$ after slaughter. Each bladder, still filled with urine, was tied at the urethra and transported on ice in an insulated container. To keep the detrusor muscle at its original stretched length a device consisting of eight injection needles $(0.6 \times 25)$ projecting through a $P V C$ board in a $3 \mathrm{~cm} \times 3 \mathrm{~cm}$ square was pinned on the anterior upper wall of each bladder. The urine volumes and bladder weights were measured.

The $3 \mathrm{~cm} \times 3 \mathrm{~cm}$ area was cut from the bladder and pinned to a silicone rubber board in one of the five modified Tyrode solutions shown in Table 1. During the whole experiment the same solution was used. Each day a different solution was chosen until every solution had been used three times. From the serosal side of the bladder wall strip a muscle bundle $15 \mathrm{~mm} \times 2 \mathrm{~mm}$ was cut and 
Table 1. The composition $(\mathrm{mmol} / \mathrm{l})$ of the buffer solutions used during the isolation procedure and measurements

\begin{tabular}{|c|c|c|c|c|c|}
\hline & \multicolumn{5}{|c|}{ Solution } \\
\hline & $0.0+$ & 0.0 & 0.18 & 1.0 & 1.8 \\
\hline $\mathrm{NaCl}$ & 137.0 & 137.0 & 137.0 & 137.0 & 137.0 \\
\hline $\mathrm{KCl}$ & 2.7 & 2.7 & 2.7 & 2.7 & 2.7 \\
\hline $\mathrm{CaCl}_{2}$ & 0.0 & 0.0 & 0.18 & 1.0 & 1.8 \\
\hline $\mathrm{MgCl}_{2}$ & 1.0 & 1.0 & 1.0 & 1.0 & 1.0 \\
\hline HEPES & 12.5 & 12.5 & 12.5 & 12.5 & 12.5 \\
\hline Glucose & 5.6 & 5.6 & 5.6 & 5.6 & 5.6 \\
\hline EGTA & 2.0 & & & & \\
\hline $\begin{array}{l}\text { Osmolarity } \\
\text { (mosmol/l) }\end{array}$ & 292 & 296 & 290 & 290 & 304 \\
\hline
\end{tabular}

The $\mathrm{pH}$ of the Ca-Tyrode buffer was adjusted to 7.5 with $\mathrm{NaOH}$ at $22^{\circ} \mathrm{C}$ and just before starting the experiment the solution was adjusted to $\mathrm{pH}=7.4$ by gassing with a $95 \% \mathrm{O}_{2} / 5 \% \mathrm{CO}_{2}$ gas mixture

carefully minced with a pair of microsurgical scissors until the diameter of the pieces of muscle was $0.5 \mathrm{~mm}$. The pieces were immersed in an enzyme solution of $3.5 \mathrm{mg}$ collagenase (Worthington CLS $1,138 \mathrm{U} / \mathrm{mg}$ ) and $3.5 \mathrm{mg}$ papain (Sigma Chemicals, crude type II, $2.8 \mathrm{U} / \mathrm{mg}$ ) dissolved in $10 \mathrm{ml}$ of the same buffer solution. The two preparations from both bladders were incubated at $37^{\circ} \mathrm{C}$ and continuously resuspended for half an hour at 15 cycles $/ \mathrm{min}$ through a wide-bore 5-ml pipette (Emergo type 10779) using a special motordriven device. The two cell-muscle suspensions were then filtered through a $350-\mu \mathrm{m}$ sieve and the solutions centrifuged for $10 \mathrm{~min}$ at $1100 \mathrm{rpm}$. The supernatant was removed and the sediment resuspended in $5 \mathrm{ml}$ buffer solution. Both cell suspensions were allowed to settle at the bottom of a PVC Petri dish with grids of $2 \mathrm{~mm} \times 2 \mathrm{~mm}$ for about $15 \mathrm{~min}$. The suspension with the highest yield and the best quality of viable cells was chosen for further experimentation.

In previous experiments the viability of isolated smooth muscle cells was checked by adding fluorescein diacetate to batches of isolated cells. It was observed that the fluorescent viable smooth muscle cells always showed a bright "halo" around the cell membrane while dead cells, which did not fluoresce, showed a black mottled appearance. In this study the cells that showed a halo in the phase contrast microscope were regarded as viable cells. Using a black and white video camera mounted on a Zeiss inverted microscope, the chosen dish was screened for the 10 viable cells with the greatest length and these cells were recorded on a U-matic videorecorder. The recordings were mixed with a video image generated by a PDP 11 computer that ran a measuring program. The length of each recorded cell was measured in a maximum of seven connecting line segments. In the same way the diameter was measured at the centre of the cell and halfway to each end of the cell. From these three measurements the mean diameter was calculated. The measured length multiplied by the mean diameter was used as an approximation of the cell area. The accuracy of the length and diameter measurements was in the order of $1 \mu \mathrm{m}$.

Statistical analysis was performed with respect to the batches isolated with the different solutions, to test the significance of the difference in cell length, diameter or area between batches (analysis of variance, Mann-Whithey $U$ (MWU) test). To test for a possible dependence of the lengths of the isolated cells on the degree of stretching of the bladders, the cells of the two bladders with the lowest and the highest urine contents from each of the three batches isolated with a given solution were also compared with the MWU test.

\section{Results}

Sixteen isolation procedures in solutions $0.0,0.18,1.0$ and 1.8 were necessary to yield 12 successful batches of cells. To obtain three successful isolations with solution $0.0+, 14$ isolation procedures were necessary. The yield from each of the 15 successful isolation procedures was $10^{3}-10^{4}$ viable smooth muscle cells independent of the solution used. Three types of smooth muscle cells could be distinguished (Figs. 1,2 and 3). In those batches that contained all three types of smooth muscle cells the cells of type 1 always were longer than cells of types 2 or 3 . Cells as in Fig. 1 were only found in batches isolated with solution $0.0+, 0.0$ or 0.18 . Cells as in Fig. 2 were found in batches isolated with solution $0.0+, 0.0,0.18$ or 1.0 . Cells as in Fig. 3 were found in all batches.

Table 2 shows the weights of the bladders used, the urine contents, the solutions used, and the mean \pm SD of the lengths, diameters and areas of the measured cells. The weights of the bladders were normally distributed according to a chi-squared test $\left(2.06, \chi^{2}=0.84\right)$. The MWU test showed a positive relation between the volume of urine and the length of isolated cells in solutions $0.0+$ and 1.8. The mean cell length was higher in bladders with the highest volume of urine than in bladders with the lowest volume.

Figure $4 a, b$ and $c$ show respectively the combined average and standard deviation of the length, diameter and area of the three batches in each solution. Analysis of variance showed a significant difference in average length, diameter and cell area; the MWU test was used to explain these differences. In the figure an asterisk indicates that the value differs significantly from the corresponding value measured in solution $0.0+$ at a significance level of $5 \%$. A decrease was found in the mean length of cells in the batches isolated with solutions $0.18,1.0$ and 1.8 relative to that in the batch isolated with solution $0.0+$. There was a significant increase in mean diameter of the cells in the batches isolated with solutions $0.0,1.0$ and 1.8 relative to that in the batch isolated with $0.0+$. Both the decrease and the increase resulted in a decrease in mean area of cells in the batches isolated with solutions $0.18,1.0$ and 1.8 relative to the cells in the batch isolated with solution $0.0+$.

\section{Discussion}

One of the three isolation procedures applied to pig bladder yielded no smooth muscle cells if solution 0.0 , $0.18,1.0$ or 1.8 was used. The isolation procedure with solution $0.0+$ had to be performed 14 times; nine times there was virtually no yield of smooth muscle cells at all. The poor results with solution $0.0+$ must be ascribed to the fact that collagenase needs calcium as a cofactor for activation. Since calcium also stabilizes the intercellular connections, the cells probably did become detached in solution $0.0+$ but remained encapsulated in the remaining collagen.

The first procedures for isolating smooth muscle cells were developed by Bagby and co-workers [2] for cells from the stomach of Bufo marinus. The cell types shown in 

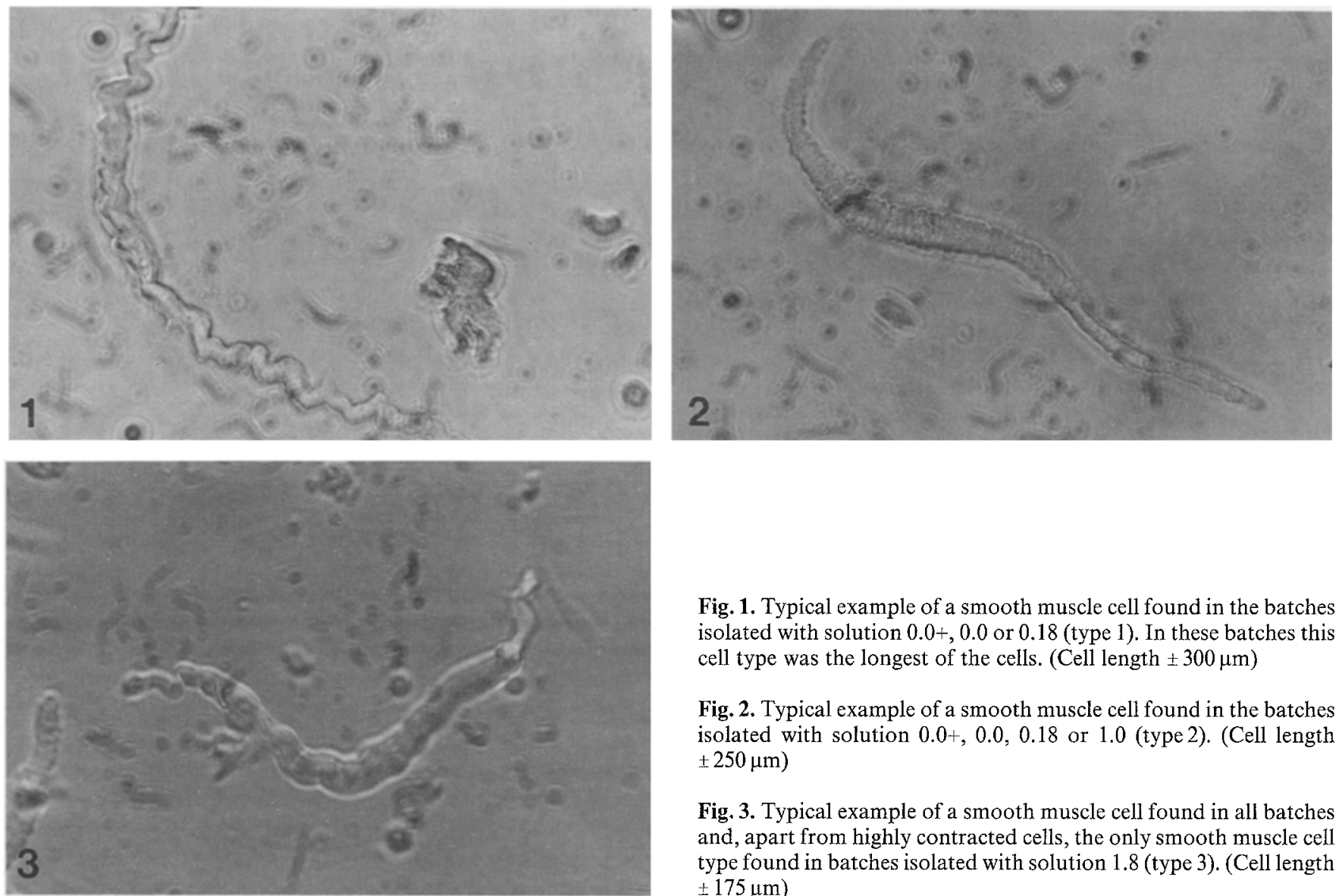

Fig. 1. Typical example of a smooth muscle cell found in the batches isolated with solution $0.0+, 0.0$ or 0.18 (type 1). In these batches this cell type was the longest of the cells. (Cell length $\pm 300 \mu \mathrm{m}$ )

Fig. 2. Typical example of a smooth muscle cell found in the batches isolated with solution $0.0+, 0.0,0.18$ or 1.0 (type 2). (Cell length $\pm 250 \mu \mathrm{m})$

Fig. 3. Typical example of a smooth muscle cell found in all batches and, apart from highly contracted cells, the only smooth muscle cell type found in batches isolated with solution 1.8 (type 3). (Cell length $\pm 175 \mu \mathrm{m})$

Table 2. The bladder weights and volume of urine in each bladder, the solutions used, and the mean \pm SD of lengths, diameters and areas of the 10 measured isolated cells from each bladder

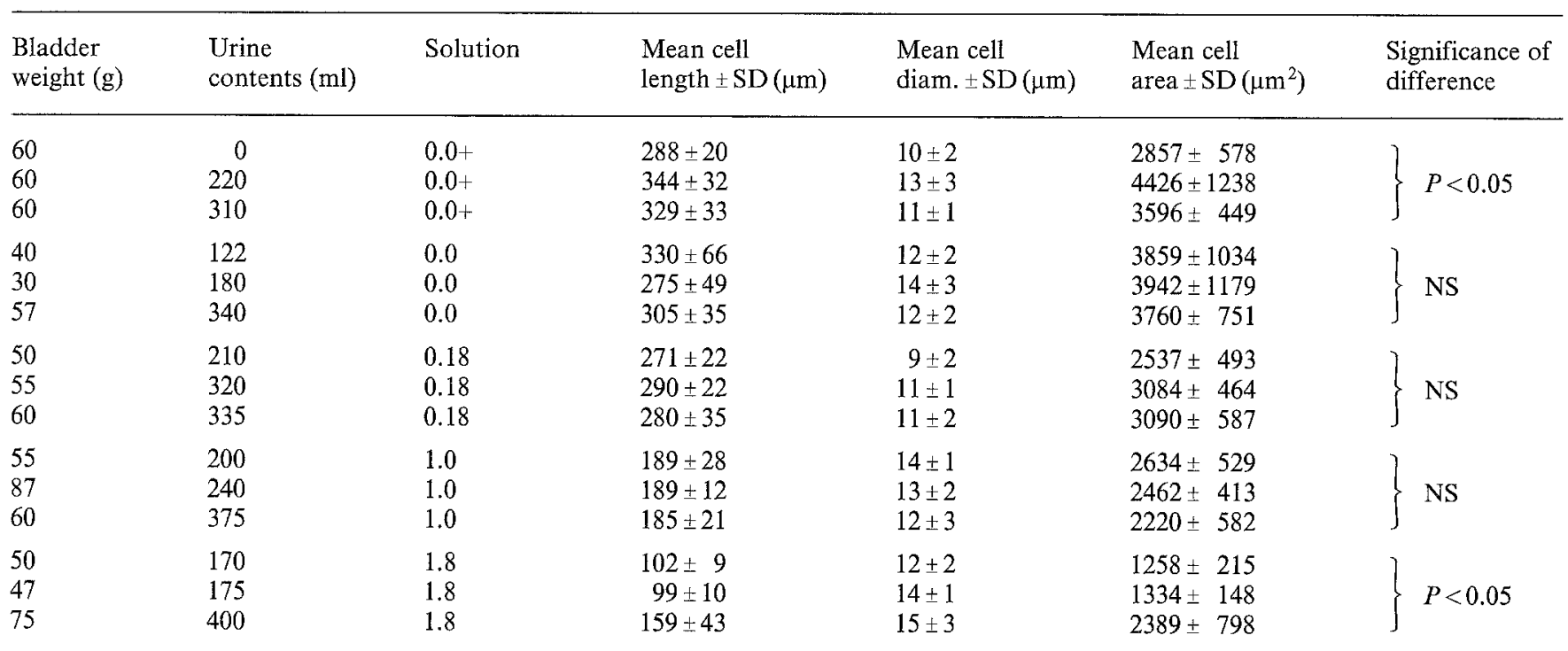

The significance of the difference between cell lengths of bladders with the lowest and highest urine contents in each solution. NS, not significant 

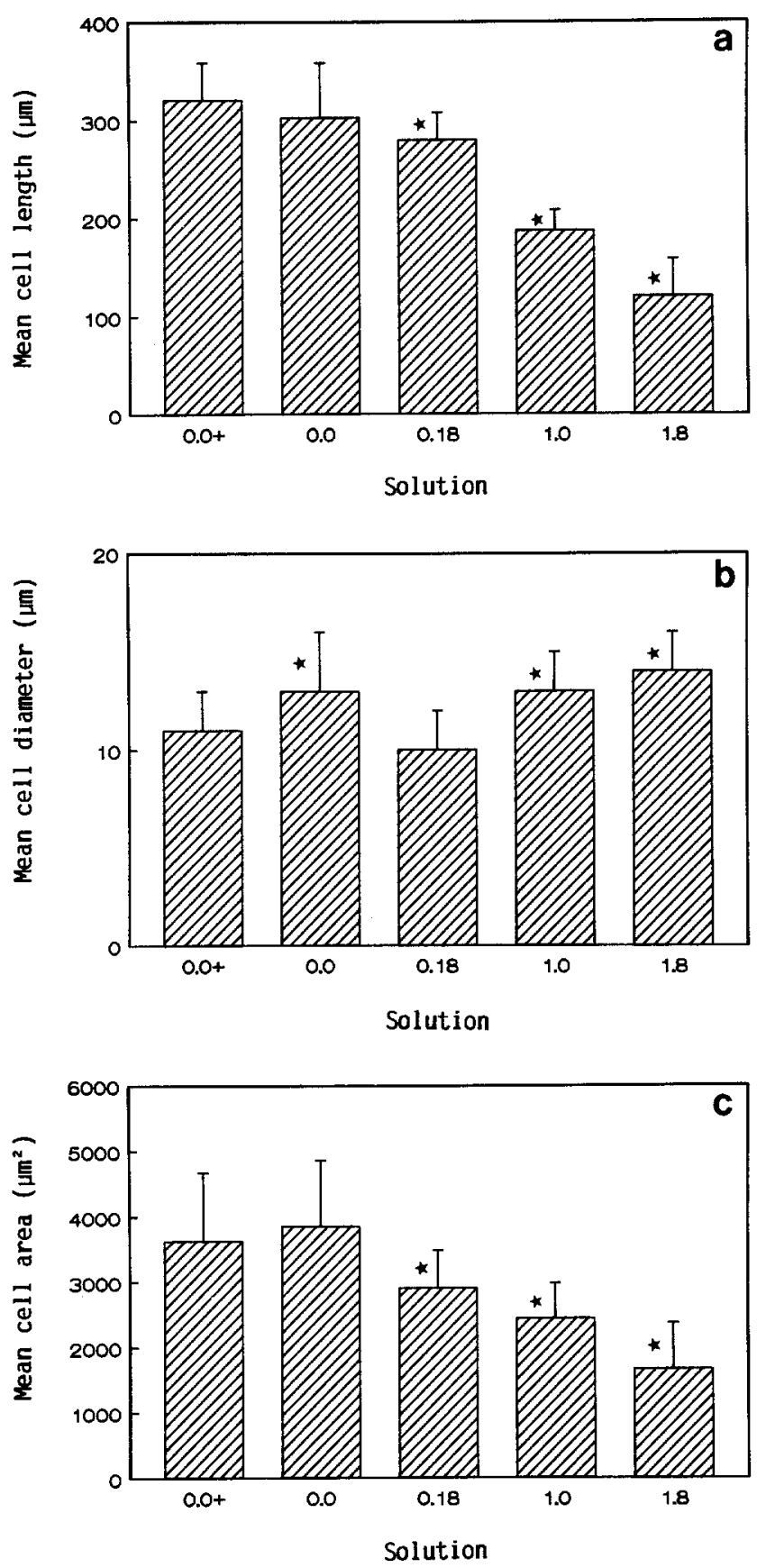

Fig. 4a-c. The mean \pm standard deviation of the cell lengths, diameters and areas of the three batches in each solution. An asterisk indicates that the value differs significantly $(P<0.05)$ from the corresponding value measured in solution $0.0+$ according to the Mann-Whitney $U$-test

Figs. 1,2 and 3 have the same morphology as these cells [8]. Cell type 1 was not found in batches isolated with solution 1.0 or 1.8 and in solution $0.0+, 0.0$ and 0.18 these were always the longest cells. It therefore seems that the cells of type 1 change into types 2 or 3 when calcium concentrations higher than $1.0 \mathrm{mmol} / 1$ are used in the isolation medium. The viability of the isolated smooth muscle cells decreased rapidly after 3-4h. In earlier experiments attempts were made to gain a larger percentage of responsive cells, as well as a longer lifespan for the cells, by substituting $10 \%$ of the buffer solutions by fetal calf serum (Sera-lab). Fifty to eighty percent of the isolated cells in this environment showed a tendency to contract spontaneously, probably as a result of hormones such as prostaglandins or insulin acting as stimulants. Cells in calcium-free solution with $2 \mathrm{mmol} / 1 \mathrm{EGTA}$, supplemented with $10 \%$ fetal calf serum, showed no spontaneous contractile response and nor did they react to acetylcholine $\left(10^{-5} \mathrm{~mol} / \mathrm{l}\right)$ or iso-osmolar $\mathrm{KCl}$ $(120 \mathrm{mmol} / 1)$.

The length of the isolated cells depended significantly on the concentration of calcium in the buffer solution. As EGTA is supposed to extract intracellular calcium in addition to binding extracellular calcium, the isolated smooth muscle cells from the batches without calcium but with EGTA added should be totally relaxed and at maximum length. The decrease in length and area during the isolation procedure at the successively higher calcium concentrations might also be ascribed to osmolarity differences between the buffer solutions. However, since the osmolarity of the solutions used ranged from 292 to $304 \mathrm{mosmol} / \mathrm{l}$ (Table 1), and these values hardly deviate from the physiological value of $300 \mathrm{mosmol} / 1$, this is not a very plausible explanation.

The apparent contractions of the smooth muscle cells during the isolation period could be due to mechanical damage to the cell membrane, or to the opening of calcium channels. In both cases calcium would enter the cell and trigger the contraction mechanism. It is obvious that many cells undergo mechanical damage during the isolation period, caused by the papain and the constant resuspension. It is not likely, however, that these damaged cells remain viable in view of the fact that calcium freely entering the cell is toxic in the extracellular concentration - which is very high compared with the physiological intracellular concentration (in the order of $10^{-8} \mathrm{~mol} / 1$ ). It is therefore most likely that calcium entered through regular channels in the cell membrane. It is known that if cells are stretched the cell membrane depolarizes and voltage-dependent calcium channels are opened. The calcium dependence of the length of the isolated cells does not imply that the cells were calcium intolerant [6]. After isolation the length of the cells remained constant, irrespective of whether the buffer solution contained calcium.

As shown in Fig. $4 \mathrm{c}$ the cell area decreased with higher calcium concentrations. If the cell is considered cylindrical or elliptical there must be a considerable volume loss at increasing concentrations of calcium, i.e. at increasing state of contraction. This volume loss has been described by Fay [7]. At present there is no evidence that the same effect is found in cells in contracting muscle bundles [3], so it may not be a physiological phenomenon in smooth muscle.

Cell length measurements were also performed on smooth muscle cells in intact muscle bundles [1] from the same bladders. No dependency of cell length on the calcium concentration of the buffer solution was found. The mean length of the smooth muscle cells was $191 \mu \mathrm{m}$ regardless whether the muscle bundles were prepared in solution $0.0+, 0.0,0.18,1.0$ or 1.8 . Compared with the cells 
in the intact muscle bundles it was found that the isolated cells in batches with solution $0.0+, 0.0$ or 0.18 were longer (MWU test, $P<0.05$ ). The cells in batches isolated with solution 1.8 were shorter $(P<0.05)$; those isolated with solution 1.0 were of comparable length. It must be concluded that some relaxation occurred after the cells were isolated. This might be due to the fact that parallel elasticity created by elements such as collagen and elastic fibres no longer exerted a force on the isolated smooth muscle cells.

A positive relation was found between the volume of urine in the bladder and the length of the smooth muscle cells isolated in solutions $0.0+$ and 1.8. One of the bladders in solution $0.0+$ contained no urine (line 1 in Table 2) and had contracted during the transport on ice, so it can only tentatively be inferred that there is a relation between length of isolated cells and stretching of the bladder.

\section{References}

1. Asselt E van, Schot R, Mastrigt R van (1991) Cell length measurements in longitudinal smooth muscle strips of the pig urinary bladder. Neurourol Urodyn 10:327

2. Bagby RM, Young AM, Fisher BA, McKinnon M (1971) Contraction of single smooth muscle cells from Bufo marinus stomach. Nature 234:351

3. Bülbring E, Brading AF, Jones, Tomita T (1981) Structure of smooth muscles. In: Gabella G (ed) Smooth muscle. Edward Arnold, London, p 38

4. Douglas WR (1972) Of pigs and men and research. Space Life Sci $3: 226$

5. Dijk AM van, Laird JD (1984) Characterization of single isolated vascular smooth muscle cells from bovine coronary artery. Blood Vessels 21:267
6. Driska SP, Porter R (1986) Isolation of smooth muscle cells from swine carotid artery by digestion with papain. Am J Physiol 251: $\mathrm{C} 474$

7. Fay FS, Delise CM (1973) Contraction of isolated smooth muscle cells: structural changes. Proc Natl Acad Sci USA 70:641

8. Fisher BA, Bagby RM (1977) Reorientation of myofilaments during contraction of a vertebrate smooth muscle. Am J Physiol 232: C5

9. Glerum JJ, Mastrigt R van, Romijn JC, Griffiths DJ (1987) Isolation and individual electrical stimulation of single smoothmuscle cells from the urinary bladder of the pig. J Muscle Res Cell Motil 8:125

10. Gosling JA, Dixon JS, Humpherson JR (1983) Gross and microscopic anatomy of the urinary bladder. In: Functional anatomy of the urinary tract. Gower Medical Publishing, London

11. Griffiths DJ, Mastrigt R van, Duyl WA van, Coolsaet BLRA (1979) Active mechanical properties of the smooth muscle of the urinary bladder. Med Biol Eng Comput 17:281

12. Koeveringe GA van, Mastrigt R van (1991) Excitatory pathways in smooth muscle investigated by phaseplot analysis of isometric force development. Am J Physiol 261:R138

13. Maruyama I, Yoshida C, Kobayashi M, Oyamada H, Momose $\mathrm{K}$ (1987) Preparation of single smooth muscle cells from guinea-pig taenia coli by combinations of purified collagenase and papain. J Pharmacol Methods 18:151

14. Maruyama I, Yoshida C, Nakayama M, Hasegawa T, Momose K (1988) Improvement of a procedure for preparing single smooth muscle cells rom guinea-pig taenia coli by purified collagenase and papain. J Pharmacol Methods 19:155

15. Mastrigt R van, Glerum JJ (1985) Electrical stimulation of smooth muscle strips from the urinary bladder of the pig. $J$ Biomed Eng 7:2

16. Mastrigt R van, Koopal JWB, Hak J, Wetering J van de (1986) Modelling the contractility of urinary bladder smooth muscle using isometric contractions. Am J Physiol 251:978

17. Schot R, Koeveringe AJ van, Mastrigt R van (1990) An improved procedure for isolating smooth muscle cells from the pig urinary bladder. J Muscle Res Cell Motil 1:86 